\title{
Green Information Technology in Indonesia- A Systematic Literature Review
}

\author{
Zahra Nurkarima Budiwati Attori ${ }^{1}$, Udisubakti Ciptomulyono ${ }^{2}$, and Satria Fadil Persada ${ }^{3}$ \\ ${ }^{1}$ Departement of Technology Management, Institut Teknologi Sepuluh Nopember, Surabaya, Indonesia \\ ${ }^{2}$ Departement of Industrial and Systems Engineering, Institut Teknologi Sepuluh Nopember, Surabaya, Indonesia \\ ${ }^{3}$ Departement of Business Management, Institut Teknologi Sepuluh Nopember, Surabaya, Indonesia \\ e-mail: zahra.19092@mhs.ac.id
}

\begin{abstract}
In Indonesia, information and communication technology (ICT) is one of the most crucial economy accelerators, for every $10 \%$ increase in the ICT investment, the nation's GDP grows as much as $1.87 \%$. However, the use of ICT leaves adverse impacts on the environment, particularly carbon emission and toxic waste. This phenomenon has led to the proliferation of the topic of environmental sustainability, one of which is green information technology (GIT). GIT is defined as the utilization of ICT that can directly or indirectly reduce the adverse impact of business processes on the environment. This paper aims to evaluate GIT research to attain a better understanding of the field of GIT in Indonesia through a literature review. Published papers are categorized and a gap analysis is presented to reveal areas that need to be explored more. The results of this study potentially serve as a guide for future studies in GIT, particularly in Indonesia. This research finds that the topic has gained popularity in recent years. There are various research themes under the topic of GIT in Indonesia, with the most explored one being the design and implementation of GIT. The majority of the studies are case-based, limiting the research scope to one particular organization. This leaves broader research objects open to be explored more.
\end{abstract}

Keywords-Green Information Technology, Environmental Sustainability, Systematic Literature Review.

\section{INTRODUCTION}

$\mathrm{T}$ HE climate change and natural degradation have been the trigger of the proliferation of environmental sustainability. Green practices are needed to be implemented in order to tackle the aforementioned environmental issue [1]. One of the most important green practices is green information technology (GIT) as business individuals and organizations rely on IT for their daily activities [2]. Information and communication technology (ICT) is one of the most substantial economy accelerators for every $10 \%$ increase in ICT investment, Indonesia's GDP grows as much as $1.87 \%$ [3]. However, the use of ICT leaves adverse impacts on the environment, particularly carbon emission and toxic waste [4]. It is estimated that ICT contributes $14 \%$ of global carbon emission to the atmosphere, and if we continue business as usual, it is projected that ICT global carbon share will increase exponentially in 2040 [5].

The term GIT is defined by IT's roles in environmental sustainability. Because of its carbon footprint and waste generated from obsolete devices, IT is considered a problem for the environment. Therefore, GIT is defined as the design, manufacture, use, and disposal of IT that has minimal to no impact on the environment [6] [7]. Green data center, optical router, and the "sleep" mode are some examples of GIT solutions [8]. However, scholars also believe that IT can

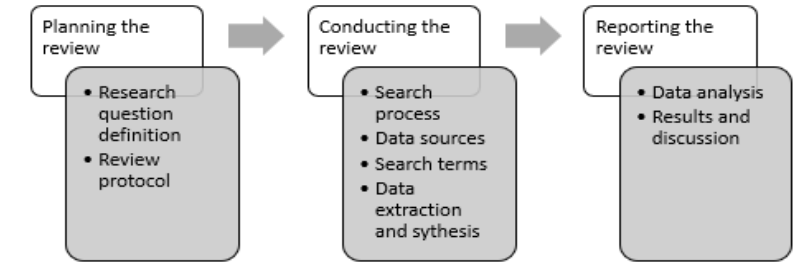

Table 1.

Terms Used in Data Extension

\begin{tabular}{|c|c|}
\hline Terms & Description \\
\hline Research ID & Identifier for each paper \\
\hline $\begin{array}{l}\text { Authors and } \\
\text { Publication Year }\end{array}$ & $\begin{array}{l}\text { Name of authors and the year when the paper } \\
\text { was published. }\end{array}$ \\
\hline Title & The title of the paper. \\
\hline Objectives & The study objectives declared in the paper. \\
\hline Object & The object of the research. \\
\hline Dataset & $\begin{array}{l}\text { The type of data collected and the size of the } \\
\text { sample. }\end{array}$ \\
\hline Methodology & $\begin{array}{l}\text { The methodology used to analyze collected } \\
\text { data, namely qualitative, quantitative, } \\
\text { literature review, conceptual, etc. }\end{array}$ \\
\hline Category & $\begin{array}{l}\text { The theme or area in which the research } \\
\text { focuses on, categorized as intention, benefit, } \\
\text { adoption, approaches, and strategies. }\end{array}$ \\
\hline Source & $\begin{array}{l}\text { The source where the paper was obtained, } \\
\text { whether from a journal or a proceeding series. }\end{array}$ \\
\hline
\end{tabular}

provide solutions for reducing or eliminating the harm caused 
Table 2.

Inclusion and Exclusion Criteria

\begin{tabular}{ll}
\hline \multicolumn{1}{c}{ Inclusion Criteria } & $\begin{array}{c}\text { Exclusion } \\
\text { Criteria }\end{array}$ \\
\hline Research relating to green information & Book \\
technology and conducted in Indonesia. & chapters. \\
Journal and proceeding papers & Incomplete \\
published in 2011-2020 & records. \\
Journal and proceeding papers written & Presentation \\
in English or Indonesian. & slides. \\
\hline \hline
\end{tabular}

to the environment by other business processes. To name a couple, carbon management system (CMS) and video conferencing are included in the GIT solutions category. CMS provides knowledge for decision-makers to support greener alternatives [4], while video conferencing allow business practitioners to attend meetings without physical attendance which requires transportation to get to the rendezvous point [8]. In a broad definition, GIT is the utilization of ICT that can directly and indirectly reduce environmental impacts caused by business activities [9]. Some terms used to refer to GIT are Sustainable IT, IT for Green, Green Computing, Green Information Systems (IS), Green IT/IS, and ICT for Sustainable Environment [10].

As GIT is gaining its popularity year after year, numerous studies have focused on many aspects of GIT. With the proliferation of the topic, scholars have attempted to map GIT published papers with various objectives, but none has concentrated on a specific country.

To understand better the current state of studies on GIT, particularly in Indonesia, this research employs a systematic literature review approach. According to Kitchenham and Charters (2007), the systematic literature review is an approach to evaluate and interpret available research which is relevant to a topic area, research question, or phenomenon of interest [11]. One of the objectives of conducting a systematic literature review is to identify the gaps in the current study so as to suggest areas for future studies [11].

\section{METHOD}

To carry out the research, a methodology proposed by Kitchenham and Charters (2007) is adopted. Similar approach has also been conducted in SLRs around the area of GIT by Anthony, Jr. et al. (2017)(2019). The methodology comprises of three main phases, they are planning, conducting, and reporting the review [12] [1]. The processes are depicted in Figure 1.

\section{A. Planning the Review}

The first phase is to plan research question and review protocol to ascertain the needs of the literature review.

\section{1) Research question}

The research questions formulated in this research are stated as follows:

RQ1: What is the importance of GIT initiatives in the context of Indonesia?

RQ2: What are the primary studies on GIT that have been addressed in Indonesia?

RQ3: What are the gaps and limitations in current Indonesian research on GIT?

2) Review protocol
Table 3.

Journals Included In The Study

\begin{tabular}{lc}
\hline \hline Journals & Frequency \\
\hline Environmental Practice & 1 \\
International Journal of Innovation and Learning & 1 \\
Test Engineering and Management. & 1 \\
Jurnal Penelitian Komunikasi & 1 \\
SISFORMA: Journal of Information Systems & 1 \\
Jurnal Sains, Teknologi dan Industri & 1 \\
Jurnal Ilmiah Teknologi Informasi Terapan & 6 \\
Jurnal Sistem Informasi & 1 \\
Journal of Industrial Engineering and Management & 1 \\
Jurnal Ilmiah Ilmu dan Teknologi Rekayasa & 1 \\
Jurnal Masyarakat Telematika dan Informasi & 1 \\
Jurnal SISFOTEK GLOBAL & 1 \\
jurnal riset komputer & 1 \\
Management: Journal of Sustainable Business and & 1 \\
Management Solutions in Emerging Economies & 1 \\
Jurnal SANTIKA & 1 \\
Journal of Information System and Technology & 1 \\
Management & 1 \\
Indonesian Journal of Educational Review & 1 \\
International Journal of Innovative Science and & 1 \\
Research Technology & 1 \\
Social Economics and Ecology Journal & 1 \\
Applied Information Systems and Management & 1 \\
Jurnal Sistem Informasi & 1 \\
Journal of Theoretical and Applied Information & 1 \\
Technology & 1 \\
Journal of Energy Technologies and Policy & 1 \\
\hline \hline
\end{tabular}

The next step is defining the review protocol by stating the inclusion and exclusion criteria. The criteria are used to filter papers so that they can fit the research. A research paper is selected if it meets the inclusion criteria and is eliminated if it meets the exclusion criteria. The inclusion and exclusion criteria are shown in Table 1 . In addition to the following criteria, it is also important to note that this review is limited by the accessibility of the published paper.

\section{B. Conducting the Review}

This phase encompasses declaring the search process, the data sources, the search terms, and the data extractions and synthesis.

\section{1) Search process}

The search process of the paper is conducted by applying the stated inclusion and exclusion criteria, full paper accessibility also restricts the search process. The search process is initially carried out by employing the Google Scholar search engine with a set of search terms. The search terms used are listed in the "search terms" subsection, and the sources of publication papers are specified in the "data source" subsection.

The initial search result returned with a total of 53 journal papers and proceeding papers, all of which satisfied the inclusion and exclusion criteria. However, some papers were not documented very well, that is, not written in a wellstructured format and language or not including information namely journal or conference name. Thus, the number of papers used is reduced to 44 . The complete reference of included articles is listed in Appendix A.

\section{2) Data source}

Papers collected were obtained from online libraries directed by Google Scholar search results. Some libraries including Research Gate, IEEE Xplore, and Taylor and Francis. Collected were a total of 44 papers in the review domain from 23 journals and 20 conference proceedings. Of 
The $2^{\text {nd }}$ International Conference on Global Development - ICODEV

Desemher $5^{\text {th }} 7000$ Online Conference

Table 4.

Conference Proceedings Included in the Study

\begin{tabular}{|c|c|}
\hline Conference Proceedings & Frequency \\
\hline $\begin{array}{l}\text { Pacific Asia Conference on Information Systems } \\
\text { (PACIS 2018) }\end{array}$ & 1 \\
\hline $\begin{array}{l}\text { 1st International Conference on Engineering and } \\
\text { Technology Development (ICETD 2012) }\end{array}$ & 1 \\
\hline $\begin{array}{l}\text { International Conference on Information } \\
\text { Management and Technology (ICIMTech) }\end{array}$ & 1 \\
\hline $\begin{array}{l}\text { 1st International Conference on Cybernetics and } \\
\text { Intelligent System (ICORIS) }\end{array}$ & 1 \\
\hline $\begin{array}{l}\text { International Conference on Information } \\
\text { Management and Technology (ICIMTech) }\end{array}$ & 1 \\
\hline $\begin{array}{l}\text { 3rd Annual Applied Science and Engineering } \\
\text { Conference (AASEC 2018) }\end{array}$ & 1 \\
\hline 5th International Conference on Information & \\
\hline $\begin{array}{l}\text { Technology, Computer, and Electrical Engineering } \\
\text { (ICITACEE 2018) }\end{array}$ & 1 \\
\hline $\begin{array}{l}\text { Conference on Information Technology, Computer } \\
\text { and Electrical Engineering (CITACEE 2013) }\end{array}$ & 1 \\
\hline $\begin{array}{l}\text { The 2nd International Conference on Applied } \\
\text { Science and Technology (iCAST 2019) }\end{array}$ & 1 \\
\hline $\begin{array}{l}\text { The 1st International Conference on Computer, } \\
\text { Science, Engineering and Technology (ICCOMSET } \\
\text { 2018) }\end{array}$ & 1 \\
\hline $\begin{array}{l}\text { The 1st International Conference on Energy, } \\
\text { Environmental and Information System (ICENIS } \\
\text { 2017) }\end{array}$ & 1 \\
\hline $\begin{array}{l}\text { International Conference in Green Technology } \\
\text { (ICGT 2019) }\end{array}$ & 1 \\
\hline $\begin{array}{l}\text { International Conference on Information Systems } \\
\text { for Business Competitiveness (ICISBC 2013) }\end{array}$ & 1 \\
\hline International Conference on Information & \\
\hline $\begin{array}{l}\text { Technology and Electrical Engineering (ICITEE } \\
\text { 2013) }\end{array}$ & 1 \\
\hline $\begin{array}{l}\text { International Conference on Science, Technology, } \\
\text { and Environment } 2019\end{array}$ & 1 \\
\hline $\begin{array}{l}\text { Seminar Nasional Inovasi dan Aplikasi Teknologi di } \\
\text { Industri } 2018\end{array}$ & 1 \\
\hline $\begin{array}{l}\text { Seminar Nasional Teknologi Informasi } \quad \text { \& } \\
\text { Komunikasi Terapan } 2012 \text { (Semantik 2012) }\end{array}$ & 1 \\
\hline $\begin{array}{l}\text { The 2nd East Indonesia Conference on Computer } \\
\text { and Information Technology (EIConCIT) } 2018\end{array}$ & 1 \\
\hline $\begin{array}{l}\text { The 3rd International Conference on Islamic } \\
\text { Education, Information Technology and Media: } \\
\text { "Challenges and Opportunities" (ICIED 2018) }\end{array}$ & 1 \\
\hline $\begin{array}{l}\text { The 6th International Conference on Cyber and IT } \\
\text { Service Management (CITSM 2018) }\end{array}$ & 1 \\
\hline Total & 20 \\
\hline
\end{tabular}

23 journals, only 3 were Scopus-indexed and 7 were Sintaindexed. The list of journals and conference proceedings included in this review is summarized in Table 2 and Table 3 , respectively.

\section{3) Search terms}

When executing the search process, the search terms included were 'Green Information Technology', 'Green Information Systems', 'Green IT', 'Green IS', 'Green Computing', 'Sustainable Information Technology', 'IT for Green', 'Green ICT', 'Sustainable ICT', and 'Indonesia', as well as the terms' translation in Indonesian. Before selecting papers to include in the review, duplication was checked carefully to make sure there was no repetition. An example is the same research published in two different journals or conference proceeding series.

\section{4) Data extraction and data synthesis}

Data extraction is applied to the selected papers by analyzing and reading each paper carefully. The purpose of the above-mentioned step is to collect relevant data related to this review. Then, data synthesis is carried out so that the research questions can be answered and the objectives of the study are attained. Items of information gained from the data extraction and analysis are presented in Table 4.

\section{Reporting the Review}

This phase is consisted of data analysis as well as results and discussion. The research questions should be answered in this phase and the objectives of giving insights into what the current state of research on GIT in Indonesia is and research gaps for discovering areas of research that are potential for future studies should be achieved. The sub phases will be discussed in the following chapter.

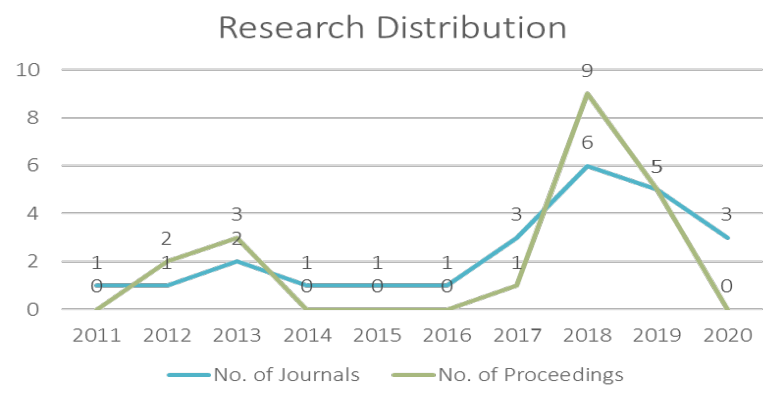

Figure 3. Journal and Proceeding Paper Distribution from 2011-2020.

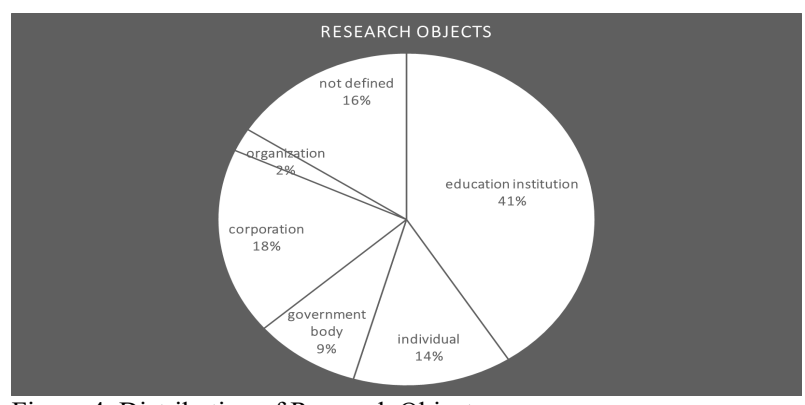

Figure 4. Distribution of Research Object.

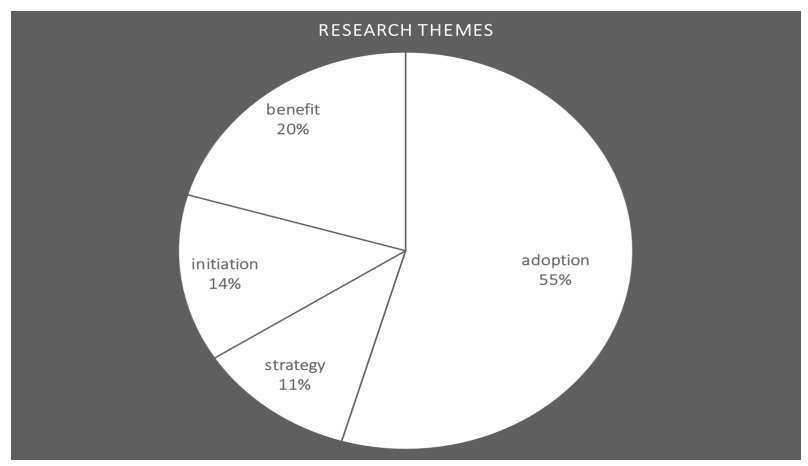

Figure 5. Distribution of Research Theme 2020.

\section{RESULT AND DISCUSSION}

The results and findings of the review were begun by reporting how the papers were selected based on the predetermined criteria. The research chosen were those in the domain of GIT that were conducted in Indonesia. Based on the data extraction and analysis, the research questions were then can be answered concurrently. 


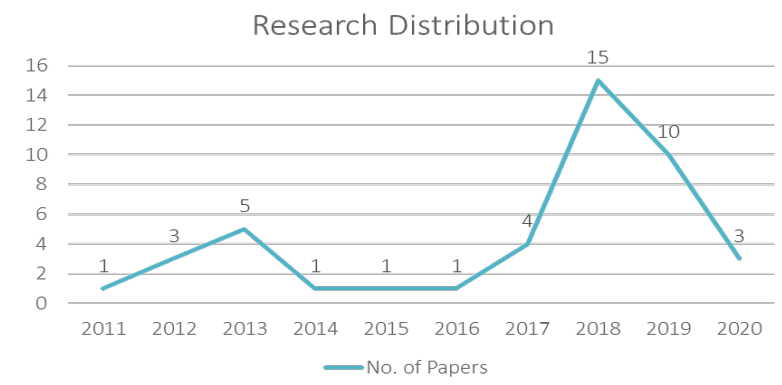

Figure 2. Research Distribution from 2011-2020.

\section{A. Overview of Current Studies}

This review is limited to studies published in the period of 2011-2020. After applying inclusion and exclusion criteria and quality assessment, 44 papers were selected. The complete list of articles included in this review can be found in Appendix A. Twenty-four studies were published in the form of journal articles and the other twenty were proceeding papers. Asadi et al. (2017) categorized research methodologies as qualitative, quantitative, mixed, review, conceptual, and design science [10]. There were 31.7\% research employing the qualitative model, $21.9 \%$ quantitative approach, and $24.4 \%$ mixed qualitative and quantitative methods. The others were $17 \%$ using design science, $7.3 \%$ review, and $4.9 \%$ conceptual.

Figure 2 illustrates the distribution of all the studies throughout this period. It can be seen from the figure that Indonesian studies regarding GIT increased gradually from 2011 to 2018. There was a brief moment when GIT gained the peak of its popularity in 2013. This might be caused by the number of international publications in the GIT domain skyrocketing and reached the summit of its all-time popularity just two years prior [10]. A decline in the interest of the topic appeared in 2019 and 2020 . However, since this study is restricted by full paper availability, it is possible that the plummeting amount of research is due to more restrictions in more recent publications.

Figure 3 represents the distribution of journal papers and proceeding papers from 2011 to 2020 . The numbers of papers in journal and proceeding publications showed similar trends. The only difference is that journal articles started slowly in 2011, peaked in 2013, declined in the following year, and gradually rose until 2018, whereas the proceeding papers came to a halt in 2014-2016. Both journal articles and proceeding articles decreased in number in 2019 and 2020. The overall number shows that there was more research in GIT published in journal articles than those in proceeding papers though the difference was not great. There were 3 International journal papers that are indexed in the Scopus database. There was one journal written by Malaysian scholars and published by Malaysian journal publisher. While almost all International conferences were hosted by Indonesian institution, one conference was hosted in South Korea, and the proceeding paper of which was published in an international proceeding series.

\section{B. The Importance of GIT Initiatives in the Context of Indonesia}

To answer the first research question, that is "what is the importance of GIT initiatives in the context of Indonesia?" we examine papers that elaborate current situations and conditions in the country that require GIT solutions. The premises stated in the papers must be supported with credible data. Fifteen papers were found to be providing the insight to answer RQ1.

The majority of the studies, 11 papers, stated that the main urgency to adopt GIT initiatives is to reduce carbon emission through energy conservation. The ICT sector releases a critical amount of carbon emission. The growing number of ICT users encourages the expansion of ICT infrastructures, which ultimately triggers a greater number of ICT use. As stated in Prasetya and Pribadi (2020), in the span of five years only, the number of ICT users in Indonesia increased by two folds. The use of ICT is a part of the overall energy consumption in Indonesia. As the largest economy in South East Asia, Indonesia consumes a great amount of electricity, which mostly is generated from coal combustion, as explained by Hermawan et al. (2017) and Yustika et al. (2017). With a combined effort from the government down to every citizen, the business, and education institution, implementation of GIT can substantially reduce the nation's carbon emission. GIT practices incorporate effective cooling, efficient energy use, and renewable energy source which can cut the consumption of fossil energy. Server consolidation and virtualization software also aid in the lessening of IT 
devices, ultimately leading to carbon emission reduction.

Other than reducing carbon emission from direct utilization of energy-efficient ICT devices, GIT solutions include teleconferencing and collaborative tools. Those GIT solutions can eliminate the need for physical meetings which require people to use transportation to get to the rendezvous point. It is mentioned by Yalina and Rozas (2019) that the Indonesian productive population reached the proportion of $68 \%$ of the total populace in 2016 , and the number will keep growing although the proportion is projected to decline. Urbanization forces the workforce to migrate to big cities. Due to the high cost of living in urban areas, migrants are pushed to the suburban or rural areas. This causes the need of commuting from their place of living to their workplace. The carbon emission produced from the use of transportation can be diminished by eliminating face-to-face meetings by utilizing collaborative tools and teleconferencing. Therefore, the need for GIT solution adoption is critical.

Two studies focus on the paperless-enabling quality of GIT and the other two concentrate on the waste management element of GIT. Through Purnawan (2018), based on a record in 2015, Indonesia loses a piece of its forest the size of 500 football fields every year. By implementing GIT solutions, paper use can be saved and tree cutting can be reduced significantly.

According to Bastina and Budiman (2017), paper is the third biggest contributor to overall waste in Indonesia, right after plastics. Every year, Indonesia produces 38.5 tons of waste, and it is likely to increase. In 2016 data disclosed by Rizkalla and Erhan (2020), Indonesia is also the secondlargest contributor to plastic waste in the sea. Those trash and garbage can be recycled to create useful IT devices. The waste of IT devices also keeps increasing, posing health risks to the surrounding living being. every individual needs to be mindful when using devices and disposing of them. It is preferable if used electronics can be recycled, refurbished, or repurposed. This practice fits the GIT definition, especially in the aspect of greening IT disposal. Cecilia and Tanamal (2020) have found that a company that incorporates GIT practice, including green disposal, gains green trust from their consumers.

\section{Current State of GIT Research in Indonesia}

To answer the first research question, the extracted then analyzed to discover the standing of Indonesian research in the area of GIT. Figure 4 illustrates research objects or scopes that the selected research focuses on.

Figure 5 represents the distribution of research themes in the domain of GIT in Indonesia. Following studies written by Brooks et al. (2010), Brooks et al. (2012), and Asadi et al. (2017), selected Indonesian GIT studies are classified into initiation, strategy, adoption, and benefit [10] [13] [14].

\section{1) Initiation}

Studies fall to this category discuss topics around the readiness or the preliminary evaluation of organizations to successfully adopt GIT initiatives.

\section{2) Strategies}

Studies in this group focus on different approaches for GIT applications and management.

\section{3) Adoption}

Research in this classification focuses on the design and implementation of GIT, as well as the driving and inhibiting factors of GIT adoption. Research examining the maturity of GIT implementation also belongs to this group.

\section{4) Benefit}

Articles with focus on the payoff of implementing GIT solutions or the environmental and economic benefits gained.

Most GIT research is focused on the measurement of the maturity of GIT implementation and the design and implementation of GIT which fall to the 'adoption' category. Other areas leave room for exploration.

\section{Research Gaps and Limitations of Current Studies}

A number of studies have been reviewed to demonstrate the understanding of GIT in the last decade, particularly in the context of Indonesia. GIT has attracted many scholars and practitioners as new a new topic, incorporating the environment in the technology of information and communication. However, there is a need for more conceptual studies relating to GIT. There are still different perspectives and definitions of GIT and the terminologies around it. Thus, there still remains unclarity surrounding the topic.

Only a few studies applied design science. Research in this area can offer contributions to providing guidelines through solution proposal for individuals and organizations in Indonesia.

Moreover, a deeper understanding of the multifaceted nature of GIT needs to be attained. Though many studies have been conducted on GIT adoption, and there is a fair amount of research on the GIT benefits, the absence of an empirical study of GIT payoff has been identified as a major gap in GIT literature, since only limited numbers of studies present the empirical evidence of environmental and economic benefits potentially generated by GIT adoption. The strategy theme is also open for exploration since it can offer value to serve as a guide for education institutions, the government, and firms to adopt GIT initiatives.

While most studies have education institutions as an object, government bodies as the policy maker would need to be addressed. As well as the corporations since the industries are the most predominant contributor in energy use, one of which is the energy consumption for ICT. Most studies used small data samples, a lot of them are case studies specified in a certain organization.

\section{CONCLUSION}

Sustainability has increasingly become an essential issue for both academic scholars and practitioners. This paper adopts a structural literature review to outline the importance of environmental sustainability, especially in IT perspectives and in the context of Indonesia. The review carried out an investigation based on three research questions. A total of 44 papers was included in this review after applying the inclusion and exclusion criteria, from 2011 to 2020. 
Findings from this review show that research in GIT in Indonesia in 2011 started with only one published research paper. Findings also tell that most scholars in Indonesia focused on a case study in a small research scope with the most popular theme being the adoption or design and implementation of GIT in a particular organization. Conducting a research with big datasets and broader research scope will offer value as there is apparent scarcity in the area.

Many research areas in GIT remain open for exploration, especially in the theme of GIT initiation, strategy, and benefit or payoff. The need for implementation guides can be satisfied with research in GIT initiation and strategy domain. Comprehensive empirical research would provide knowledge regarding the environmental and economic impact of GIT adoption for firms. As the industry is the biggest contributor of carbon emission by sector, evidence of potential economic benefit would encourage corporations to start or increase the extent to which they incorporate GIT practices in the daily business operations.

Future studies might consider the research gaps presented in this review to provide a theoretical contribution to GIT literature in Indonesia. Decision makers could benefit from the knowledge brought forth by the updated studies in GIT, especially in the context of Indonesia.

\section{REFERENCES}

[1] B. Anthony Jr., M. A. Majid and A. Romli, "Green information technology adoption towards a sustainability policy agenda for government-based institutions," Journal of Science and Technology Policy Management, vol. 10, no. 2, pp. 274-300, 2019.

[2] S. Dezdar, "Green information technology adoption: influencing factors and extension of theory of planned behavior," Social Responsibility Journal, vol. 13, no. 2, 2017.

[3] B. Martawardaya, A. S. Nugroho and A. H. Firdaus, "Institute for Development of Economics and Finance," 2018. [Online]. Available: https://indef.or.id/research/detail/peran-investasi-sektor-teknologiinformasi-dan-komunikasi-tik-serta-paten-terhadap-pertumbuhanekonomi-indonesia. [Accessed 2511 2020].

[4] R. Nishant, T. S. H. Teo and M. Goh, "do shareholders value green information technology announcements?," Journal of the Association for Information Systems, vol. 18, no. 8, pp. 542-576, 2017.

[5] L. Belkhir and A. Elmeligi, "Accessing ict global emissions footprint: trends to 2040 \& recommendation," Journal of Cleaner Production, vol. 177, pp. 448-463, 2018.

[6] S. P. Chuang and S. J. Huang, "The effect of environmental corporate social responsibility on environmental performance and business competitiveness: the mediation of green information technology," Journal of Business Ethics, vol. 150, no. 4, pp. 991-1009, 2018.

[7] K. Walsh, "CIO," 2007. [Online]. Available: https://www.cio.com/article/2437751/environmentally-sustainable-itdefinition-and-solutions.html. [Accessed 16 November 2020].

[8] M. T. Majeed, "Information and communication technology (ict) and environmental sustainability in developed and developing countries," Pakistan Journal of Commerce and Social Sciences, vol. 12, no. 3, pp. 758-783, 2018.

[9] R. Nishant, Understanding the Payoffs from Sustainability, Singapore: National University of Singpore, 2014.

[10] S. Asadi, A. R. C. Hussin and H. M. Dahlan, "Organizaitonal research in the field of green it: a systematic literature review from 2007 to 2016," Telematics and Informatics, vol. 34, pp. 1191-1249, 2017.

[11] B. Kitchenham and S. Charters, in Guidelines for Performing Systematic Literature Reviews in Software Engineering, Keele University and University of Durham, 2007, p. 1051.

[12] B. Anthony Jr., M. Abdul Majid and A. Romli, "Green information technology system practice for sustainbale collaborative enterprise: a structural literature review," International Journal of Sustainable Society, vol. 9, no. 3, pp. 242-272, 2017.

[13] S. Brooks, X. Wang and S. Sarker, "Unpacking Green IT: A Review of the Existing Literature," in AMCIS, Lima, Peru, 2010
[14] S. Brooks, X. Wang and S. Sarker, "Unpacking Green IS: A Review of the Exising Literature and Directions for the Future," in Green Business Process Management, Berlin, Heidelberg, Springer, 2012, pp. 15-37. 